УДК 330.5

DOI: $10.15673 /$ fie.v11i4.1544

\author{
Савенко I.I. \\ доктор економічних наук, профресор \\ кафедра менеджменту та логістики \\ E-mail: kaf-ml@gmail.com \\ ORCID ID: 0000-0008-5217-1478 \\ Седікова I.O. \\ доктор економічних наук, профессор \\ кафедра менеджменту та логістики \\ Одеська національна академія харчових технологій \\ вул. Канатна, 112, м. Одеса, Україна, 65039 \\ E-mail: irina-sedikova@ukr.net \\ ORCID ID: 0000-0003-4376-1267
}

\title{
ЕКОНОМІЧНА БЕЗПЕКА ПІДПРИЄМСТВА: ПІДХОДИ ДО ВИЗНАЧЕННЯ
}

Зміна політичної обстановки наприкінці XX століття змінила сутність функціонування України. Проблема, що стоїть перед Україною, має двоїсте протиріччя: з одного боку необхідність інтегруватися в світову економіку, з іншого, забезпечити внутрішню економічну інтеграцію, захист свого внутрішнього ринку і національних інтересів. Рішення даної задачі можливе при наявності надійної системи економічної безпеки держави, регіонів, підприємства, індивіда.

Стаття присвячена дослідженню проблематики щодо «діагностики економічної безпеки підприємств», наведено авторське визначення сутності поняття «економічна безпека сільськогосподарського підприємства» - це такий стан функціональних секторів підприємства, його менеджменту та партнерських зв'язків, які забезпечують підприємству довготривале функціонування в складі конкурентоспроможного технологічного ланцюгу на ринку сільськогосподарської продукції. Рекомендовано метод діагностування економічної безпеки підприємства в основу якого покладено бюджетування. Рекомендовано авторську методику з визначення рівня безпеки підприємства.

Ключові слова: діагностика, економічна безпека, сільськогосподарське підприємство, чинники впливу, методи діагностування.

This work is licensed under a Creative Commons Attribution 4.0 International License http://creativecommons.org/licenses/by/4.0/

Постановка проблеми та її зв'язок з важливими науковими та практичними завданнями. Зміна світової політичної структури наприкінці XX ст. в повному розумінні змінила сутність функціонування ряду республік Радянського союзу. Ця доля не обминула і створену при розвалі Радянського союзу нову державу Україну. Функціонування у складі союзу і самостійна діяльність в світовій економіці виявилися далеко не однозначними. Сутністю розвитку світової економіки виступає процес зіткнення та узгодження інтересів різних держав в тому числі і не завжди мирним шляхом. Проблема, яка постала перед Україною, має дуальне протиріччя: 3 одного боку необхідність інтегруватися у світову економіку, з іншого - гарантування внутрішньої інтеграції, зокрема економічної, захист національного ринку та національних інтересів. Вирішення означеної задачі можливо за умов наявності потужної системи економічної безпеки держави, регіонів, підприємства, індивіда.

Аналіз останніх публікацій по проблемі. Проблема економічної безпеки підприємств та іiї діагностика $\epsilon$ однією з актуальних у організації ефектив- ного функціонування підприємств різних галузей національної економіки. Важливість проблеми пояснює інтерес та поглиблене вивчення їх закордонними та вітчизняними науковцями. Широкий охват досліджуваних аспектів проблеми економічної безпеки підприємств продукує багатогранність трактування даного поняття, що відрізняються різноманітністю підходів за змістом. Проблемі стану економічної безпеки та іiі діагностики присвячені роботи науковців, серед яких: 3. Варналій, С. Васильчак, В. Глухова, Н. Гічової, С. Довбні, І. Доценко, С. Ілляшенка, Г. Козаченко, О. Ляшенко, С. Марченко, О. Новікова, В. Пономарьова, О. Резнікова, І. Федоренко та інших.

Разом 3 тим існує ряд невирішених питань пов'язаних 3 практичними аспектами діагностики економічної безпеки держави, регіонів, залишаються недостатньо дослідженими методи діагностування підприємств, в тому числі сільськогосподарських, відсутні методики системного підходу до вирішення означеної проблеми.

Формування цілей дослідження. Основною ціллю наукової статті виступає розробка системного 
підходу до діагностики стану економічної безпеки підприємств аграрного сектора. Для досягнення поставленої цілі були вирішені наступні завдання: досліджено правові основи формування економічної безпеки; досліджено погляди науковців щодо сутності понять «діагностика» та «економічна безпека підприємства»; сформулювало авторське бачення сутності поняття «економічна безпека сільськогосподарського підприємства»; узагальнено схему системного підходу до діагностики стану економічної безпеки сільськогосподарського підприємства, обгрунтовано метод діагностування економічної безпеки підприємства в основу якого покладено бюджетування.

Виклад основних результатів та їх обгрунтування. Проблема економічної безпеки є першочерговою для існування країни, регіону, підприємства та індивіда. Правові підвалини сутності та механізму формування економічної безпеки задекларовано в законах та правових актах України. У Декларації «Про державний суверенітет України» (1990р.) державний суверенітет визначено «...як верховенство, самостійність, повноту і неподільність влади Республіки в межах ii території та незалежність і рівноправність у зовнішніх зносинах» [1], головні цілі та принципи економічної самостійності України, як незалежної держави, подано у Законі «Про економічну самостійність України» [2], ст. 17 Конституції України наголошує, що «...захист суверенітету і територіальної цілісності України, забезпечення іiі економічної та інформаційної безпеки є найважливішими функціями держави, справою всього українського народу» [3]. Концепція «Національної безпеки України» визначає що «...стан захищеності життєво важливих інтересів особи, суспільства та держави від внутрішніх і зовнішніх загроз, є необхідною умовою збереження та примноження духовних і матеріальних цінностей». У даному документі прописані основні можливі загрози національній безпеки в політичній, економічній, соціальній, воєнній, екологічній, науково-технічній та інформаційній сферах життєдіяльності [4]. Як бачимо, в переліку основних можливих загроз присутня економічна безпека. Однак з 1990 року і до нагального часу в Україні відсутня Концепція економічної безпеки держави, при тому, що в Міністерстві економіки України у 1995 році було розроблено відповідний проект документу, який і досі офіційного статусу не набув. Можливо за нового складу Верховної Ради, Кабінету міністрів та Президенту буде затверджено Концепція економічної безпеки України і держава отримає вельми важливий документ у сфері економічної безпеки.

Характеристика рівня економічної безпеки підприємства визначається його діагностикою. Існує багато визначень терміну «діагностика». Згідно тлумачного словника: «діагностика - це галузь знань, що вивчає теоретичні, практичні аспекти, методи проведення процесів діагностування, а також принципи іiі побудови». Можливі варіанти терміну «діагностика» за словником Мультитран це - «оцінка», «пошук неполадок» чи «виявлення помилок».

Розкриттю змісту терміну «діагностика економічної безпеки» підприємства присвячено чисельні статті науковців. Так Сак Т. В. розглядає діагностику економічної безпеки підприємства, комплексу оцінка всіх складових (фінансової, правової, трудової, інтелектуальної, силової, техніко-технологічної) безпеки 3 метою отримання максимально рівня безпеки від загроз (внутрішніх/зовнішніх), задля прийняття превентивних управлінських рішень та розробку ефективної стратегії [5]. Глухов В., Бахрамов Ю. вважають що «діагностика економічної системи - це проведення аналізу з з'ясовування цілей підприємства, шляхів їх досягнення та визначення недоліків» [6]. В. Верби та Т. Решетняк у роботі [7] визначають, що задля «забезпечення своєї економічної безпеки підприємство використовує сукупність корпоративних ресурсів, розуміючі під корпоративними ресурсами - фактори бізнесу, які використовують власники та менеджери підприємства, для досягнення цілей.

$€$. Коротков надає наступне визначення терміну [8] «діагностика - це визначення стану об'єкта, предмету, явища або процесу управління шляхом реалізації комплексу дослідницьких процедур, виявлення в них слабких ланок і вузьких місць».

Аналіз трактування поняття «економічна безпека підприємства» вітчизняними науковцями. В наукових роботах Ілляшенко С., Олейникової $€$., Кузенко Т., Варналій 3. в основу визначення покладено ефективність використання ресурсів системи [11-14]. Визначення економічної безпеки підприємства через стан виробничої системи рекомендують науковці Лисенко Ю., Міщенко Р. Тамбовцев В. [15-16]. Шликов В. та в «Енциклопедії економічної безпеки» здійснюється аналіз економічної безпеки підприємства за допомогою захищеності життєво важливих інтересів підприємства [7-18]. Наявність конкурентних переваг покладено в основу аналізу економічної безпеки підприємства В. Бєлокуровим В. [19]. Д. Ковальов, Т. Сухорукова, [20] розглядають дану категорію за станом захищеності діяльності підприємства. За гармонізацією економічних інтересів досліджують економічну безпеку підприємства Г. Козаченко, В. Пономарьова, О. Ляшенко [21]. Найбільш повторюваним $є$ визначення економічної безпеки підприємства, як сукупності підприємницького потенціалу та корпоративних ресурсів, за якою досягається максимальний ефект їх використання задля ефективного функціонування та розвитку підприємства, попередження загрозам(внутрішніх/ зовнішніх).

Аналіз трактування та розкриття суті поняття «економічна безпека підприємства» вітчизняними науковцями, дає змогу зробити висновок, що економічна безпека підприємства виступає комплексною характеристикою стану підприємства, яка показує рівень його захищеності від дію екзогенних та ендогенних чинників (флуктуацій), та запобіганню його переходу в стан не конкурентоспроможності та банкрутства в тривалій перспективі.

Для протидії негативним флуктуаціям необхідно розвивати визначені властивості соціальноекономічних систем, якими виступають сільськогосподарські підприємства: витривалість (властивість зберігати функціональні здібності; толерантність (властивість сприймати різні параметри середовища; резистентність (властивість протидіяти негативним факторам середовища); стійкість (властивість підтри- 
мувати власну життєздатність); еластичність (властивість відновлювати свої функціональні здібності) [22].

Автори надають наступне визначення терміну економічної безпеки сільськогосподарського підприємства - це такий стан функціональних секторів підприємства, його менеджменту та партнерських зв'язків, які забезпечують підприємству довготривале функціонування в складі конкурентоспроможного технологічного ланцюгу на ринку сільськогосподарської продукції.

Проведений аналіз наукових праць дозволив зробити висновок, що на дані фазі розвитку більш уваги приділяється методичними розробкам визначення економічної безпеки на національному, регіональному рівні, якщо розглядати рівень підприємства, то не існує єдиного комплексного методичного підходу іï до аналізу та оцінки. Економічній безпеці підприємства об'єднує множину якісних та кількісних показників (фінансові, виробничі, трудові, логістичні, правові, інноваційні, інвестиційні тощо). Підгрунтям оцінки кількісного рівня економічної безпеки підприємства $\epsilon$ індикаторний, ресурснофункціональний, програмно-цільовий підходи та підхід на основі теорії економічних ризиків.

В основу індикаторного підходу покладено зіставлення фактичних показників діяльності підприємства 3 індикаторами, що виступають пороговими значеннями цих показників і відповідають певному рівню безпеки. Даний підхід дає можливість визначити загальний станом економічної підприємства (безпечний чи небезпечний; кризовий, критичний, передкризовий, нормальний).

Сутність методу полягає у визначенні загроз по кожній категорії. Якщо хоча б один індикатор переходить передкризовий поріг, то вважається, що підприємство знаходиться в стані небезпеки. Рівень економічної безпеки вважається досягнутим, якщо всі індикатори знаходяться в межах своїх допустимих значень. Складністю індикаторного підходу виступає точність визначення значень індикаторів, що є основою якості визначення рівнів економічної безпеки.

В основі ресурсно-функціонального підходу лежить визначення рівня економічної безпеки підприємства методом оцінювання ефективності використання ресурсів підприємства. При застосування даного методу необхідна розробка комплексу заходів щодо визначення видів загроз за кожним напрямом діяльності та оцінки економічного ефекту, ототожнюючи його із аналізом стану фінансово-господарської діяльності. Даний метод дозволяє визначити рівень економічної безпеки в динаміці.

Програмно-цільовий підхід передбачає інтегрування показників, які визначають рівень економічної безпеки підприємства. Складність при використанні цього підходу полягає у відборі показників та визначенню методів їх інтегрування, при встановленні коефіцієнтів значущості на основі методів експертних оцінок.

Підхід на основі теорії економічних ризиків заснований на визначенні різних загроз підприємства та розрахунку збитків. Збитки порівнюються 3 величиною прибутку, доходу та майна.

Різновидом в індикаторному підході є графі- чний метод В. Шлемко [22] який дозволяє візуальне сприйняття зон нормального, критичного та передкризового рівнів та графічне визначення рівня економічної безпеки аналізованого підприємства.

Методику співвідношення величини бруттоінвестицій підприємства та величини інвестиційних ресурсів, необхідних для підтримки умов, що забезпечують економічну безпеку запропонував Г. Козаченко [23].

Згідно методики, рівень економічної безпеки підприємства коливається у діапазоні 0 - 1. Чим ближче величина співвідношення до одиниці, тим вище рівень економічної безпеки. Основною проблемою при оцінці за даними методом це визначення рівня інвестицій.

Рекомендовано авторську методику 3 визначення рівня безпеки підприємства, сутність якої полягає у визначенні співвідношення величин фактично затрачених інвестицій підприємством на підтримання рівня економічної безпеки до величини інвестиційних ресурсів, необхідних для створення умов, що забезпечують економічну безпеку. Величину необхідних ресурсів слід розраховувати, як приведену величину інвестицій за функціональним критерієм підприємства - лідера галузі.

На рис. 1 рамках ресурсно-функціонального та комплексного підходу узагальнено композиції складових економічної безпеки підприємства за функціональною ознакою (рис. 1).

Аграрна галузь України, яка призвана забезпечувати населення продуктами харчування, а переробну промисловість сировиною, сьогодні стикається 3 досить актуальними проблемами: недостатня і неефективна державна підтримка; занепад сільської місцевості; низький рівень забезпеченості обладнання та сільськогосподарською технікою; низький рівень забезпеченості фінансовими ресурсами, кризове зменшення робочих місць. На фоні означених проблем економічна безпека сільськогосподарських підприємств є вельми актуальна. Враховуючи, що сільськогосподарське підприємство є самостійною соціальноекономічною системою, складовою національної та світової економік, складові економічної безпеки підприємства слід виокремити в три групи: внутрішні складові безпеки; політичні, економіко-організаційні та соціальні складові безпеки національного характеру та чинники пов'язані із природно-кліматичними умовами; складові безпеки міжнародного характеру.

Погоджуючись 3 методикою визначення рівня економічної безпеки підприємства науковців А. Ткаченко та О. Резнікова за функціональними секторами виробництво, збут, фінанси та відносин праці, автори вважають за доцільне розширити коло секторів та доповнити їх перелік функціональними секторами: інформаційне забезпечення; логістика (постачання, складування, транспортування, сервісна діяльність, управління запасами): інноваційна діяльність; інвестиційна діяльність; маркетингова діяльність, діяльність за функціями управління (цілеполагання, планування, прогнозування, регулювання, організація, мотивація, контроль, облік); соціальна сфера; екологія; якість, техніко-технологічна забезпеченість, інтелектуально-кадрова, силова, ринкова, політикоправова. 


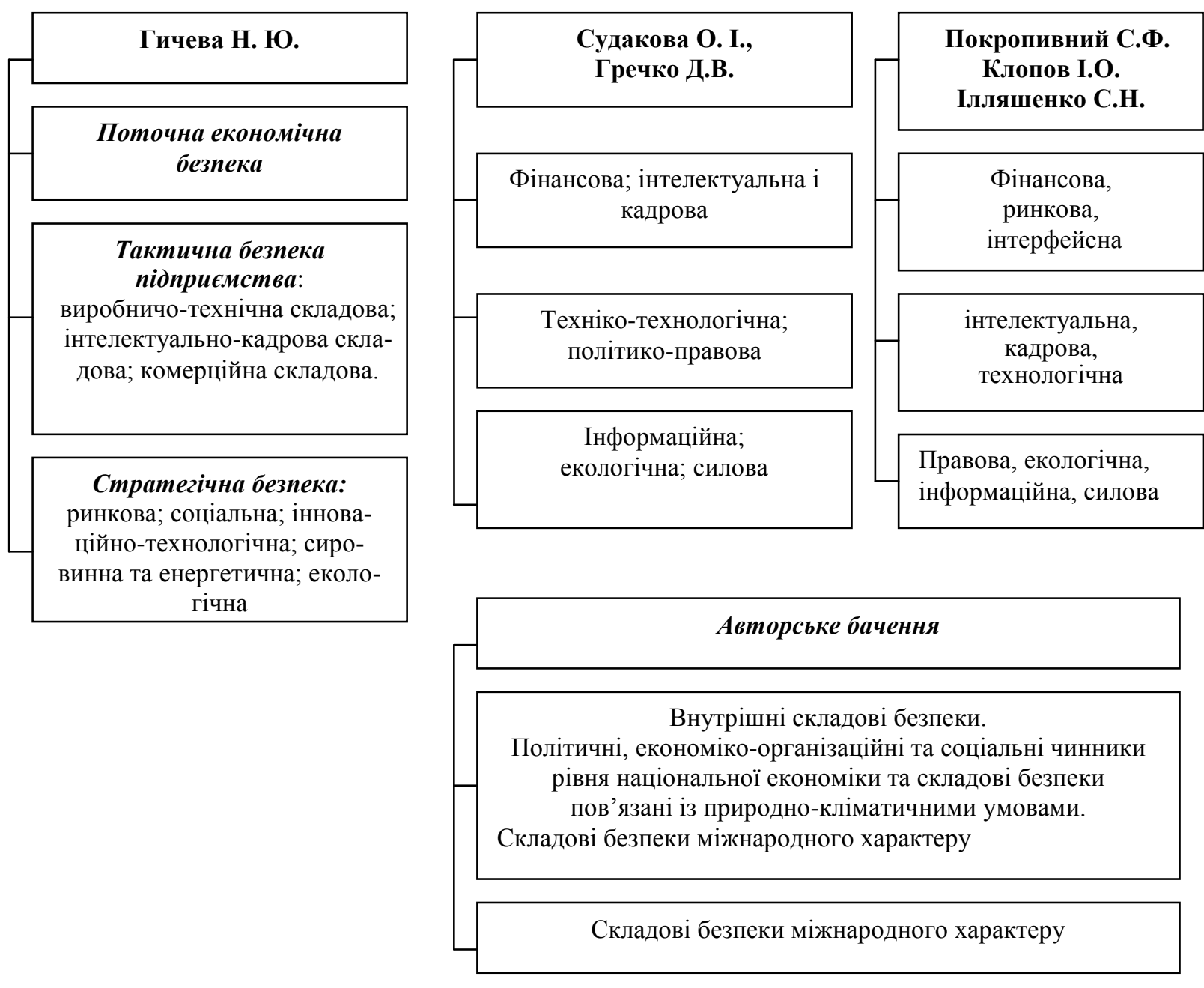
Рис. 1. Композиції складових економічної безпеки підприсмства за функціональною ознакою*
* власна розробка авторів

Висока ефективність методики досягається за умов бюджетування всіх секторів та видів діяльності підприємства.

До політичних, економіко-організаційних та соціальних складових безпеки національного характеру слід віднести: захищеності національних інтересів, готовності інститутів влади створювати механізми захисту національної економіки забезпечити іiі здатність зберігати та поновлювати процес суспільного відтворення і соціально-політичної стабільності суспільства, державний протекціонізм; політикоправову, законодавчу базу; фінансово-кредитну систему; конкуренти; інвестори; кредитори; логістичні оператори,

До складових безпеки пов'язаних із природно-кліматичними умовами слід віднести природнокліматичні умови; специфіка агрокліматичних зон; агрокліматичне районування.

До міжнародних складових безпеки слід від нести чинники політичного, військового, зовнішньоекономічного характеру, ринкові, світову фінансовокредитну систему; світовий ринок продукції аграрного сектору, ринок сільськогосподарської техніки та запасних частин до неї, конкуренція світових виробників сільськогосподарської продукції,

Висновки та перспективи подальших досліджень. В роботі досліджено правові основи формування економічної безпеки України, які прописані в ряді нормативних та правових актах; досліджено погляди науковців щодо сутності понять «діагностика» та «економічна безпека підприємства»; сформулювало авторське бачення сутності поняття «економічна безпека сільськогосподарського підприємства»; обгрунтовано метод діагностування економічної безпеки підприємства в основу якого покладено бюджетування, узагальнено підхід до діагностики стану економічної безпеки сільськогосподарського підприємства. 


\section{Література}

1. Декларація про державний суверенітет України: Декларація // Відомості Верховної ради УРСР. Київ: Верхова Рада України №31, 1990. 1-10 с.

2. Про економічну самостійність України: Закон України від 12.10. 1994 за станом на 02.10.2018p. // Відомості Верховної ради УРСР. Київ: Верхова Рада України №142-ХII, 1994. 1-10 с.

3. Конституція України: Закон України від 28.06.1996 №254к/96-ВР // Відомості Верховної ради УРСР. Київ: Верхова Рада України №30, 1996. 25-30 с.

4. Сак Т.В. Діагностування рівня економічної безпеки підприємства в умовах обмеженості інформації / Миколаївський національний університет імені В.О. Сухомлинського. Миколаїв, 2016. Т. 5, вип. 16. С. 404-408.

5. Бахрамов Ю.М., Глухов В.В. Финансовый менеджмент: учеб. пособ. М.: Лань, 2006. 736 с.

6. Верба В.А., Решетняк Т.І. Організація консалтингової діяльності: посібник. Київ, 2010. 241 с.

7. Антикризисное управление: посібник / за ред. С. М. Короткова. М.: ІНФРА-М, 2000. 432 с.

8. Коллас Б. Управление финансовой деятельностью предприятия: учеб. пособ. М.: Финансы, 2010. 576

p.

9. Овчаренко Ю.А. Діагностування економічної безпеки підприємства // Ефективна економіка. Економічна наука. 2015. Т. 5, вип. 11. С. 45-56.

10. Ильяшенко С.Н. Составляющие экономической безопасности предприятия и подходы к их оценке // Актуальні проблеми економіки. 2013. Т. 1, вип. 3. С. 11-19.

11. Олейникова Е.А. Основы экономической безопасности (государство, регион, предприятие, личность): учеб. пособие. М.: ЗАО «Бизнес-школа «Интел-Синтез», 2006. 288 с.

12. Кузенко Т.Б. Планування економічної безпеки підприємства в умовах ринкової економіки: автореф. дис. ... канд. екон. наук: 08.06.01: захист 12.04.2004 / наук. кер. Полій Г. Ф. Європейський ун-т фінансів, інформаційних систем, менеджменту і бізнесу, 2004. 18 с.

13. Варналій 3.С. Економічна безпека: навч. посіб. Київ: Знання, 2009. 647 с.

14. Мищенко, С.Г., Руденский, Р.А., Лысенко Ю.Г. Механизмы управления экономической безопасностью: навч. посіб. Донецьк: ДонНУ, 2002. 178 с.

15. Тамбовцев В.Л. Теории институциональных изменений: учебн. пособ. М.: Инфрам-М, 2009. 260 с.

16. Шлыков В.В. Комплексное обеспечение экономической безопасности предприятия: учебник. СпБ: Алетейя, 2015. $312 \mathrm{c}$.

17. Економічна енциклопедія: у 3 т. Т. 2. / ред.кол. С. В. Мочерний. К.: ВЦ «Академія», 2000. 898 с.

18. Белокуров В.В. Структура функциональных составляющих экономической безопасности предприятия. Одеса, 2019. URL: http://www.safetyfactor.ru (дата звернення: 7.10.2019). C. $48-51$.

19. Ковалев Д. І. Экономическая безопасность предприятия // Экономика Украины. 2008. Т. 2, вип. 10. 2013. $280 \mathrm{c}$.

20. Козаченко Г.В. Економічна безпека підприємства: сутність та механізм забезпечення. К.: Лібра,

21. Мельник Л.Г. Теория самоорганизации экономических систем: монографія. Суми: Университетская книга, 2015. $439 \mathrm{c.}$

22. Шлемко В.Т. Економічна безпека України: сутність і напрямки забезпечення: монографія. К.: Національний ін.-т стратегічних досліджень, 2007. 149 с.

23. Козаченко А.В. Економічна безпека підприємства: сутність і механізм забезпечення: монографія. К.: Лібра, 2017. 354 с.

Савенко И.И.

доктор экономических наук, профессор кафедра менеджмента и логистики

E-mail: kaf-ml@gmail.com

ORCID ID: 0000-0008-5217-1478

Седикова И.А.

доктор экономических наук, профессор кафедра менеджмента и логистики

Одесская национальная академия пищевых технологий

ул. Канатная, 112, г. Одесса, Украина, 65039

E-mail: irina-sedikova@ukr.net

ORCID ID: 0000-0003-4376-1267

\section{ЭКОНОМИЧЕСКАЯ БЕЗОПАСНОСТЬ ПРЕДПРИЯТИЯ: ПОДХОДЫ К ОПРЕДЕЛЕНИЮ}

Изменение политической обстановки в конце XX века изменила сущность функционирования Украины. Проблема, стоящая перед Украиной, имеет дуальное противоречие: с одной стороны необ- 
ходимость интегрироваться в мировую экономику, с другой - обеспечить внутреннюю экономическую интеграцию, защиту своего внутреннего рынка, собственного товаропроизводителя и национальных интересов. Решение данной задачи возможно при наличии надежной системы экономической безопасности государства, регионов, предприятия, индивида.

Статья посвящена исследованию проблематики диагностики экономической безопасности предприятий, приведено авторское определение сущности понятия «экономическая безопасность сельскохозяйственного предприятия» как состояния функциональных подсистем предприятия, менеджмента предприятия и его партнерских связей, обеспечивающих предприятию долгосрочное функционирование в составе конкурентоспособной технологической цепи на рынка сельскохозяйственной продукции.

Рекомендуется метод диагностики экономической безопасности предприятия в основу которого положен принцип бюджетирования. Рекомендовано авторскую методику определения уровня безопасности предприятия, сущность которой заключается в определении соотношения величин фактически затраченных инвестиций предприятием на поддержание уровня экономической безопасности к величине инвестиционных ресурсов, необходимых для создания условий, обеспечивающих экономическую безопасность. Величину необходимых ресурсов следует рассчитывать, как приведенную величину инвестиций по функциональному критерию предприятия - лидера отрасли.

Осуществлена классификация экономической безопасности сельскохозяйственных предприятий по внутреннимм; политическим, экономико-организационным, социальным признакам и связаными с природно-климатическими условиями и международным характером.

Ключевые слова: диагностика, экономическая безопасность предприятия, факторы влияния, метод диагностирования.

\author{
Savenko I. \\ Doctor of Economics, Professor \\ Department of Management and Logistics \\ E-mail: kaf-ml@gmail.com \\ ORCID ID: 0000-0008-5217-1478 \\ Sedikova I. \\ Doctor of Economics, Professor \\ Department of Management and Logistics \\ Odessa National Academy of Food Technologies \\ Kanatna str., 112 Odesa, Ukraine, 65039 \\ E-mail: irina-sedikova@ukr.net \\ ORCID ID: 0000-0003-4376-1267
}

\title{
ECONOMIC SECURITY OF AN ENTERPRISE: APPROACHES TO THE DEFINITION
}

Changing of political situation in the late twentieth century completely changed the essence of Ukraine functioning. The problem that Ukraine confronted has a dual contradiction: on the one hand the need to integrate into the world economy, on the other hand to ensure internal economic integration, protect its internal market, its own producer and national interests. The solution to such a problem is possible in the presence of a powerful system of economic security of the state, regions, enterprise, individual.

The article is devoted to the research of problems concerning «diagnostics of economic security of enterprises», the author defines the essence of the concept «economic security of agricultural enterprise» this is the state of functional sectors of the enterprise, its management and partnerships that provide the enterprise with long-term functioning in the competitive technological chain on the agricultural market.

The method of diagnosing the economic security of the enterprise based on budgeting has been recommended. The author's method for determining the level of security of the enterprise, the essence of which is to determine the ratio of the amount of actually spent investments by the enterprise to maintain the level of economic security to the amount of investment resources needed to create conditions that provide economic security, has been recommended. The amount of the resources required should be calculated as the reduced value of investments by the functional criterion of the enterprise - the industry leader.

The classification of components of economic security of agricultural enterprises has been made according to the internal signs: political, economic, organizational, social, national, and climate-related and international. sis.

Keywords: diagnostics, economic security of the enterprise, factors of influence, method of diagno- 


\section{References}

1. Verkhova Rada Ukrainy № 31. (1990). Deklaratsiia pro derzhavnyi suverenitet Ukrainy: Deklaratsiia. Kyiv.

2. Verkhova Rada Ukrainy №142-XII. (1994). Pro ekonomichnu samostiinist Ukrainy: Zakon Ukrainy vid 12.10.1994 za stanom. Kyiv.

3. Verkhova Rada Ukrainy №30. (1996). Konstytutsiia Ukrainy: Zakon Ukrainy vid 28.06.1996 №254k/96-Vr za stanom. Kyiv.

4. Sak, T. V. (2016). Diahnostuvannia rivnia ekonomichnoi bezpeky pidpryiemstva v umovakh obmezhenosti informatsii. Mykolaivskyi Natsionalnyi Universytet Imeni V.O. Sukhomlynskoho, 5(16), 404-408.

5. Bahramov, Yu. M., \& Gluhov, V. V. (2006). Finansovyiy menedzhment. Moscow: Lan.

6. Verba, V. A., \& Reshetniak, T. I. (2010). Orhanizatsiia konsaltynhovoi diialnosti. Kyiv.

7. Korotkova, E. M. (Ed.). (2000). Antikrizisnoe upravlenie. Moscow: INFRA-M.

8. Kollas, B. (2010). Upravlenie finansovoy deyatelnostyu predpriyatiya. Moscow: Finansyi.

9. Ovcharenko, Yu. A. (2015). Diahnostuvannia ekonomichnoi bezpeky pidpryiemstva. Efektyvna Ekonomika. Ekonomichna Nauka, 5(11), 45-56.

10. Ilyashenko, S. N. (2013). Sostavlyayuschie ekonomicheskoy bezopasnosti predpriyatiya i podhodyi k ih otsenke. Aktualni Problemy Ekonomiky, 1(3), 11-19.

11. Oleynikova, E. A. (2006). Osnovyi ekonomicheskoy bezopasnosti (gosudarstvo, region, predpriyatie, lichnost). Moscow: ZAO «Biznes-shkola «Intel-Sintez».

12. Kuzenko, T. B. (2004). Planuvannia ekonomichnoi bezpeky pidpryiemstva $v$ umovakh rynkovoi ekonomiky (Doctoral dissertation). [Abstract]. 1-18. (UMI No. kand. ekon. nauk: 08.06.01).

13. Varnalii, Z. S. (2009). Ekonomichna bezpeka. Kyiv: Znannia.

14. Mischenko, S. G., Rudenskiy, R. A., \& Lyisenko, Yu. G. (2002). Mehanizmyi upravleniya ekonomicheskoy bezopasnostyu. Donetsk: DonNU.

15. Tambovtsev, V. L. (2009). Teorii institutsionalnyih izmeneniy. Moscow: Infram-M.

16. Shlyikov, V. V. (2015). Kompleksnoe obespechenie ekonomicheskoy bezopasnosti predpriyatiya. Saint Petersburg: Aleteyya.

17. Mochernyi, S. V. (Ed.). (2000). Ekonomichna entsyklopediia (Vol. 2). Kyiv: VTs «Akademiia».

18. Belokurov, V. V. (2019). Struktura funktsionalnyih sostavlyayuschih ekonomicheskoy bezopasnosti predpriyatiya. Retrieved October 7, 2019, from http://www.safetyfactor.ru

19. Kovalev, D. I. (2008). Ekonomicheskaya bezopasnost predpriyatiya. Ekonomika Ukrainyi, 2(10), 48-51.

20. Kozachenko, H. V. (2013). Ekonomichna bezpeka pidpryiemstva: sutnist ta mekhanizm zabezpechenniaEkonomichna bezpeka pidpryiemstva: sutnist ta mekhanizm zabezpechennia. Kyiv: Libra.

21. Melnik, L. G. (2015). Teoriya samoorganizatsii ekonomicheskih sistem. Sumi: Universitetskaya kniga.

22. Shlemko, V. T. (2007). Ekonomichna bezpeka Ukrainy: sutnist i napriamky zabezpechennia. Kyiv: Natsionalnyi in.-t stratehichnykh doslidzhen.

23. Kozachenko, A. V. (2017). Ekonomichna bezpeka pidpryiemstva: sutnist i mekhanizm zabezpechennia. Kyiv: Libra.

Received 20 October 2019

Approved 3 November 2019

Цитування згідно ДСТУ 8302:2015

Available in Internet 26.12.2019

Савенко I.І., Седікова І.О. Економічна безпека підприємства: підходи до визначення // Економіка харчової промисловості.

2019. Т.11, вип. 4. С. 35-41. doi: 10.15673/fie.v11i4.1544

Cite as APA style citation

Savenko, I., \& Sedikova, I. (2019). Economic security of an enterprise: approaches to the definition. Food Industry Economics, 11(4), 35-41. doi: 10.15673/fie.v11i4.1544 